\title{
Growth, Photosynthesis and Yield of Chickpea as Influenced by Urban Wastewater and Different Levels of Phosphorus
}

\author{
Hamid Iqbal Tak ${ }^{1, *}$, Faheem Ahmad ${ }^{1}$, O.O Babalola ${ }^{1}$, Arif Inam ${ }^{2}$ \\ ${ }^{1}$ Department of Biological Sciences, Faculty of Agriculture, Science and Technology, North-West University, Mafikeng Campus, \\ Private Bag X2046, Mmabatho 2735, South Africa \\ ${ }^{2}$ Environmental and Plant Physiology Lab, Department of Botany, Aligarh Muslim University, Aligarh, 202002, India
}

\begin{abstract}
The use of effluents or marginal water in agriculture is an unavoidable practice and its largest source is the urban wastewater. In order to evaluate its effect on agricultural crops, an experiment was conducted to study its impact on Cicer arietinum L. along with different levels of phophorus. Three levels of water used for irrigation included ground water $(\mathrm{GW})$, $50 \%$ wastewater $(50 \% \mathrm{WW})$ and $100 \%$ wastewater $(100 \% \mathrm{WW})$ and the varying levels of phosphorus $\left(\mathrm{P}_{0}, \mathrm{P}_{20}, \mathrm{P}_{40}, \mathrm{P}_{60}\right)$ were also applied along with the basal application of nitrogen and potassium at the rate of 15 and $20 \mathrm{~kg} \mathrm{ha}^{-1}$ respectively. The effect was evaluated on the basis of growth, biochemical attributes, photosynthesis and yield of the crop. From the results it was clear that the wastewaters proved not only effective source of water but the nutrients also and enhanced growth and photosynthetic capacity and thereby yield of the plants. Moreover the fertilizer (P) requirement of the crop was also reduced. In conclusion the urban wastewater showed no inhibitory effect on the growth of the crop and thus could effectively supplement not only the nutrient requirement of the crop but may also act as the source of water.
\end{abstract}

Keywords Wastewater, Phosphorus, Photosynthesis, Yield and Chickpea

\section{Introduction}

The problem of water shortage dictates the utilization of marginal water for irrigation and its improper use poses challenges to self sufficiency in food production. Of the current list of 30 or so countries that have per capita runoff of less than $1,700 \mathrm{~m}^{3}$ per year, almost all are net importers of more than 20 percent of their grain requirement. The net import of these water deficient countries already exceeds 25 percent of the global grain trade[1]. If countries like India and China with so much of their population join the water deficit group in couple of decades, the strain on the exporting countries may certainly become unsustainable. Despite growing concern over water shortages and food security, irresponsible overuse and misuse of water continue unabated. Rainfall over land is the main source of fresh water fit for the agriculture and human consumption. Out of the annual rainfall, a good amount of water evaporates back into the atmosphere which is called "Green Water" and is the source of water for all non irrigated vegetation including forests, wood lands and rain fed crops. After allowing for

* Corresponding author:

hamid.iqbal2007@gmail.com (Hamid Iqbal Tak)

Published online at http://journal.sapub.org/plant

Copyright (C) 2012 Scientific \& Academic Publishing. All Rights Reserved evaporation from continental rainfall nearly 40,000 billion $\mathrm{m}^{3}$ of fresh water enters lakes, reservoirs, streams and aquifers in active exchange with the surface waters. This is called "Blue Water". It is not only unevenly distributed but also transient as it also evaporates or flows into unusable water sinks such as sea or salt pans. While the remaining surface water is also not wholly accessible, as it flows to remote inaccessible destinations where it is not in demand and sometimes also polluted during its flow as a result of the anthropogenic activities[2,3].

India is a developing and industrially fast growing country. It is one of the most densely populated land spaces of the earth. A few monsoon months starting from June to August bring copious rainfall. Its land area of 3.29 million $\mathrm{km}^{2}$ has an annual precipitation of $117 \mathrm{~cm}$. Out of this 4000 billion $\mathrm{m}^{3}$ of rainfall, due to limitation in storing the flood flows of the monsoon rain, only 690 billion $\mathrm{m}^{3}$ of surface water and 450 billion $\mathrm{m}^{3}$ ground water remain fit for use. But due to uneven distribution of water availability over time and space we have typical flood-drought syndrome prevailing in several parts of the country and against these estimates of water availability, we have the demand projection of around 1000 billion $\mathrm{m}^{3}$ with in next few years[4]. According to the Central Pollution Control Board of India (CPCB), the total wastewater generated by industry in 2004-05 was $26,254 \mathrm{ML} / \mathrm{d}[5]$. The actual figure is likely to 
be more. With the industrial growth and GDP growing at about $8-9 \%$ per year, water consumed by industry is likely to be even higher than the previous year and thus the generation of wastewater too. Thus the largest source of marginal water for agriculture is the municipal wastewater in other words the urban wastewater. This water often contains higher levels of salts such as bicarbonates, sodium, chlorides, and sulfates than fresh water that may reduce plant performance and yield quality. Treated effluents are also characterized by higher levels of organic matter, total suspended solids (TSS), nutrients, microelements, and microorganisms than the potable water from which they originated, which may affect the irrigated plants[6].

Anthropogenic activities have significantly altered the environment throughout the world including mining, industry and agriculture as well as increase of the urbanization level. For example, on one hand many chemical fertilizers from various ore that cannot be regenerated are decreasing gradually. On the other hand, however, the discharge of wastewater containing abundant nutrients have been considered as the important cause contributing to the eutrophication of water[7]. Many countries throughout the world are approaching or have already reached the limits of their available water supplies. Since agriculture involves the consumptive use of water and fertilizer, therefore, the use of additional water resources of marginal quality or the wastewater can increase the volume of water available for irrigation and may supplement the nutrient requirement of the crop. Sufficient scope therefore, exists for conservative and sustainable use of water in agriculture and improvement in its equitable distribution among users by adopting a variety of measures such as:

$>$ Varietal improvement of crops for higher water use efficiency.

$>$ Effective soil water management.

$>$ Agronomic management and choice of the crops with low water budget.

$>$ Need based or demand driven irrigation.

$>$ Using water of marginal quality.

Thus the present study was aimed to evaluate the effect of urban waste water along with different phosphorus levels on plant morphology, fresh and dry yield, photosynthetic activity and yield of the crop. In addition the heavy metal contents of the waste water and soil samples were also analyzed however, the microbial characteristics were determined only for wastewater.

\section{Materials and Methods}

The urban wastewater includes the wastewater from the households and sewage together with wastewater from local industries of locks and electroplating as well and was collected from the outskirts nearly $5 \mathrm{~km}$ from the town where it is already being used to irrigate the crops by the local farmers. Thus pot experiment was carried out in the naturally illuminated net house of the department of Botany
Aligarh Muslim University, Aligarh, and each treatment was set simultaneously in triplicate using a completely randomized block design, with four different phosphorus treatments being watered by tap water $(\mathrm{GW})$ and urban wastewater $(50 \% \mathrm{WW}$ and $100 \% \mathrm{WW})$. The surface of the seeds was disinfected with $0.01 \%$ aqueous solution of mercuric chloride followed by repeated washing with double distilled water (DDW). The disinfected seeds were then inoculated with specific Rhizobium and were sown in earthen pots (10 inch diameter), filled with sandy loam soil mixed with farmyard manure. Tap water $(\mathrm{GW})$ and urban wastewater (WW) characteristics were monitored at the beginning and before the end of experiment.

Water samples were collected just before irrigation and were analyzed for physico-chemical characteristics adopting the procedures as outlined in the Standard Methods[8] (Table 1). The soil samples of the experimental pots were collected before the start of the experiment. These samples were also analyzed for standard physico-chemical properties according to Jackson[9] and Ghosh et al.,[10] (Table 3). Microbiological analysis was also carried out and the mean values were obtained from three random samples (Table 2). Heavy metals $(\mathrm{Cd}, \mathrm{Pb}, \mathrm{Ni}, \mathrm{Cr})$ in the water and the soil samples were also analyzed using the atomic absorption spectrophotometer (Table 1 and 3 ).

Table 1. Physico-chemical characteristics of ground water (GW) and wastewater (WW) given in $\mathrm{mgl}^{-1}$ or as specified.

\begin{tabular}{|c|c|c|c|c|c|}
\hline \multirow{2}{*}{$\begin{array}{c}\text { Determina- } \\
\text { tions }\end{array}$} & \multicolumn{2}{|c|}{ Ground Water } & \multicolumn{2}{c|}{ Wastewater } & \multirow{2}{*}{$*$ FAO } \\
\cline { 2 - 5 } $\mathrm{pH}$ & Before & After & Before & After & \\
\hline $\mathrm{EC} \mathrm{ds} / \mathrm{m}^{-1}$ & 0.92 & 7.6 & 8.2 & 7.8 & $6.5-8.4$ \\
\hline $\mathrm{TDS}$ & 610 & 560 & 1045 & 1325 & $<2000$ \\
\hline Total solids & 970 & 890 & 1740 & 1945 & - \\
\hline $\mathrm{Ca}^{2+}$ & 15.4 & 26.53 & 51.36 & 59.84 & $<400$ \\
\hline $\mathrm{Mg}^{2+}$ & 28.2 & 22.48 & 148.57 & 137.59 & $<61$ \\
\hline $\mathrm{Na}^{+}$ & 25.52 & 21.26 & 44.61 & 61.24 & $<460$ \\
\hline $\mathrm{Cl}^{-}$ & 48.71 & 52.42 & 132.41 & 143.84 & $<350$ \\
\hline $\mathrm{K}^{+}$ & 4.94 & 5.42 & 21.44 & 18.24 & $<2.0$ \\
\hline $\mathrm{PO}_{4}^{-3}$ & 0.36 & 0.17 & 1.28 & 1.42 & $<2.0$ \\
\hline $\mathrm{CO}_{3}^{-2}$ & 53.4 & 69.25 & 148.74 & 136.25 & - \\
\hline $\mathrm{HCO}_{3}^{-1}$ & 104 & 82.48 & 79.48 & 92.58 & $<610$ \\
\hline $\mathrm{NO}_{3}-\mathrm{N}$ & 0.94 & 0.90 & 148.25 & 3.42 & $<10.0$ \\
\hline $\mathrm{NH}_{4}-\mathrm{N}$ & 0.12 & 0.09 & 3.95 & 3.74 & 5.0 \\
\hline $\mathrm{Cd}$ & $\mathrm{ND}$ & $\mathrm{ND}$ & 0.007 & 0.006 & - \\
\hline $\mathrm{Cr}$ & $\mathrm{ND}$ & $\mathrm{ND}$ & 0.007 & 0.007 & - \\
\hline $\mathrm{Ni}$ & $\mathrm{ND}$ & $\mathrm{ND}$ & 0.472 & 0.483 & - \\
\hline $\mathrm{Pb}$ & $\mathrm{ND}$ & $\mathrm{ND}$ & 0.029 & 0.032 & - \\
\hline
\end{tabular}

*FAO Ayers and Wescot, (1994) Dash(-) means no standard developed, (ND)- Not detected

The plants taken out of each pot were sampled at 60 days after sowing (DAS). The samples were washed gently to remove adhering soil. The Plant length and fresh mass of the whole plant was assessed. The plants were then dried in an oven, run at $80^{\circ} \mathrm{C}$ for $48 \mathrm{~h}$. and the dehydrated plants were weighed to record dry mass. Similarly, at each sampling, from the additional set of plants, the root nodules were separated to record their fresh and dry mass, after dehydrating them in the same way as the whole plant. Leaf 
area was measured using a portable leaf area meter (LA-21, Systronics, India). Nitrate reductase (NR) activity was determined in fresh leaves of plants by the method of Jaworsky[11] and net photosynthetic rate $\left(\mathrm{P}_{\mathrm{N}}\right)$ and stomatal conductance $\left(\mathrm{g}_{\mathrm{s}}\right)$ at each stage of sampling were measured in upper most fully expanded leaves on clear sunny days between 1100 and $1230 \mathrm{~h}$, using portable photosynthetic system (LICOR 6400, Lincoln, NE, USA). Leaf nitrogen was estimated by the method of Lindner[12] while the method of Mackinney[13] was used to calculate the total chlorophyll content. At harvest, yield attributes including seeds per pod, pods per plant, 100 seed weight, seed yield per plant were noted and protein content in the seeds was measured by the method of Lowry et al.[14].

Table 2. Microbiological characteristics of the urban wastewater

\begin{tabular}{c|cc}
\hline Bacteria & Method used & Bacterial count \\
\hline Total heterotrophic & Spread Plate & $28.4 \times 10^{6} \mathrm{CFU}$ \\
bacteria & method & $100 \mathrm{ml}^{-1}$ \\
Coliforms & MPN method & $1.9 \times 10^{3} 100 \mathrm{ml}^{-1}$ \\
Faecal coliforms & MPN method & $7.2 \times 10^{2} 100 \mathrm{ml}^{-1}$ \\
\hline Salmonella-Shigella sp & Spread plate method & $1.3 \times 10^{2} 100 \mathrm{ml}^{-1}$ \\
\hline
\end{tabular}

Table 3. Physico-chemical characteristics of soil. All determinations in $\mathrm{mgl}^{-1}$ in 1:5 (soil:water) extract or as specified

\begin{tabular}{|c|c|}
\hline Determinations & Soil \\
\hline Texture & Sandy loam \\
\hline Texture & 3.42 \\
\hline CEC (meq $100 \mathrm{~g}^{-1}$ soil) & 7.69 \\
\hline $\mathrm{pH}$ & 0.350 \\
\hline Organic carbon $(\%)$ & 282.00 \\
\hline $\mathrm{EC}\left(\mu\right.$ mhos $\left.\mathrm{cm}^{2}\right)$ & 0.307 \\
\hline$-\mathrm{NO}_{3}-\mathrm{N}\left(\mathrm{g} \mathrm{kg}^{-1}\right.$ soil $)$ & 0.109 \\
\hline Phosphorus $\left(\mathrm{g} \mathrm{kg}^{-1}\right.$ soil) & 10.2 \\
\hline Potassium & 27.15 \\
\hline Calcium & 17.38 \\
\hline Magnesium & 30.52 \\
\hline Chloride & 26.25 \\
\hline Carbonate & 92.43 \\
\hline Bicarbonate & 13.98 \\
\hline Sodium & 17.01 \\
\hline $\mathrm{Cd}\left(\mu \mathrm{g} \mathrm{g}^{-1}\right)$ & 0.18 \\
\hline $\mathrm{Cr}\left(\mu \mathrm{g} \mathrm{g}^{-1}\right)$ & 0.042 \\
\hline $\mathrm{Ni}\left(\mu \mathrm{g} \mathrm{g}^{-1}\right)$ & 0.72 \\
\hline $\mathrm{Pb}\left(\mu \mathrm{g} \mathrm{g}^{-1}\right)$ & 0.69 \\
\hline
\end{tabular}

*E.C- Electrical conductivity

\section{Data analysis}

The data recorded from the experiment was subjected to two way analysis (ANNOVA) using SPSS software package and the means were compared following the method given by Gomez and Gomez[15].

\section{Results and Discussion}

The analysis of the urban wastewater has revealed that it was alkaline and the average $\mathrm{EC}, \mathrm{pH}$, TDS and the observed nutrients including some heavy metals also were within the permissible limits of FAO guidelines for irrigation water quality except for $\mathrm{Mg}^{2+}$ and $\mathrm{K}^{+}[16]$ though all were higher than that of ground water. The major effect of EC and TDS on crop productivity is the inability of the plants to compete with ions present in the soil for water while the chloride content of $143.84 \mathrm{mg} \mathrm{l}^{-1}$ was also comparatively low and may not cause toxicity problems. When nutrients are added through effluents and they are either equal or less than the demand of the crop, the build up in the soil is normally minimal. There are reports where it has been shown that the continuous use of effluents may result in the accumulation of nitrate in the soil[17] and is subject to move to down layers which may ultimately result in the contamination of ground water. Similarly NPK fertilizers added at the rate higher than the rate of crop removal accumulate in the soil therefore, a balance between the wastewater and fertilizer dose has to be identified. Although in various studies, dilution has been described as an effective means to minimize toxicity however, under current experimental conditions since the source of irrigation was the urban sewage wastewater which was sufficiently diluted repeatedly due to the mixing of the household wastewater did not cause any toxicity problems.

The wastewater contained considerable amount of nutrients which are considered essential for maintaining the soil fertility as well as for enhancing the plant growth and productivity. Wastewater in general proved beneficial in increasing the plant growth characteristics and dry matter accumulation was higher in plants receiving it as a source of irrigation water compared to those receiving ground water (GW). $100 \%$ WW recorded much more dry mater among the two concentrations of water used. This is primarily due to the retention of the effluent components mainly due the incorporation of the elements in the dry matter of plants[18] leading to decreasing concentration in the surrounding ground and surface waters. Wastewater contained nitrogen in both nitrate as well as in the form of ammonia and as the vegetative growth includes formation of new leaves, stems and roots, the involvement of $\mathrm{N}$ through protein metabolism controls them. This was also clearly indicated by the observed enhanced growth and $\mathrm{N}$ content in the leaves under the wastewater irrigation (Fig. 3). Suitability of $\mathrm{NH}_{4}^{+}$or $\mathrm{NO}_{3}{ }^{-}$for the growth and development of plants depends upon many factors[19]. However, normally the highest growth rate and plant yield are obtained by combined supply of both and therefore, in the present study, the improvement in growth could be due to the cumulative effect of ammonium as well as nitrate ions together. It is noteworthy that applied $\mathrm{NH}_{4}{ }^{+}-\mathrm{N}$ is toxic for some higher plants including bean and pea[20], however, in presence of $\mathrm{NO}_{3}{ }^{-}-\mathrm{N}$, it has been reported to benefit sunflower[21], wheat[22] and chickpea[18] and thus the observed nutritional superiority of the wastewater (containing both ammonium-N and nitrate-N) for growth of chickpea was not exceptional and possibly explains the reason of better performance of the crop grown under the its irrigation. Another possible explanation of the increased dry matter is possibly because of the increased leaf area and expansion (Fig. 2) 
which might have influenced the light absorption within a plant causing stimulation of $\mathrm{P}_{\mathrm{N}}$ (Fig. 2), thereby optimizing the $\mathrm{CO}_{2}$ assimilation and photosynthetic production. The increase in the leaf area brought about by $\mathrm{N}$ supply causing the expansion of the individual leaves was also reported by Taylor et al.[23] and Gastal and Lemaire[24] which may be through its effect on cell division and cell expansion[25] Similarly increased $\mathrm{N}$ supply has also been found to enhance the activities of CA and RuBP carboxylase as reported by Terashima and Evans[26] and the stimulation in the activity of CA as observed in the present study (Fig. 3).
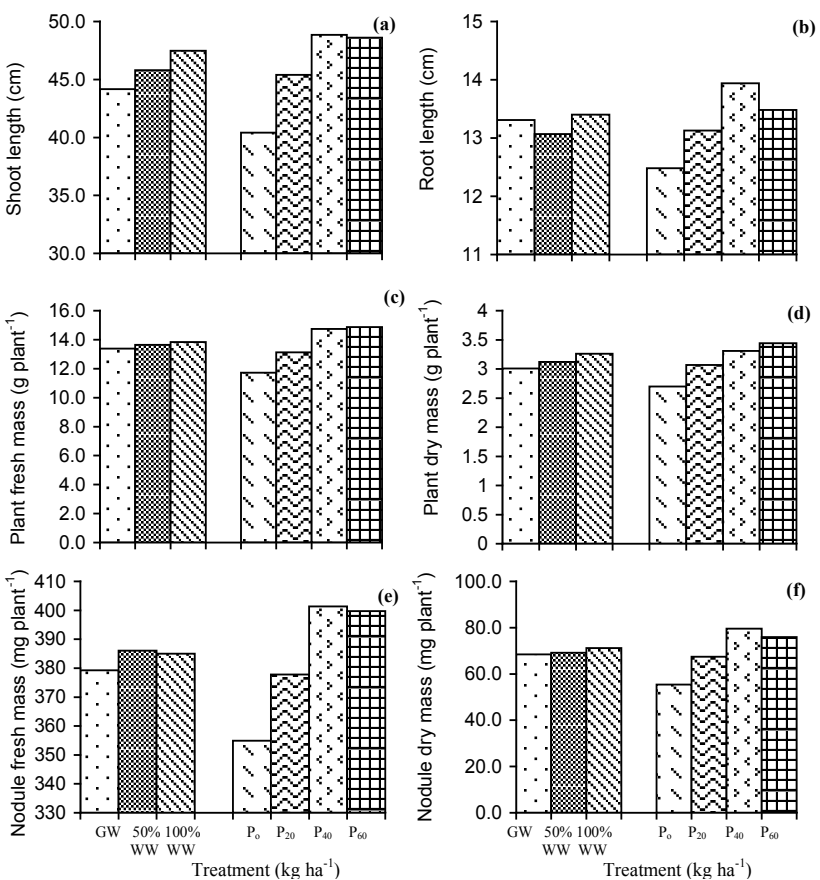

Figure 1. Figure showing the effect of different waters and phosphorus on (a) shoot length (b) root length, (c) plant fresh mass, (d) plant dry matter, (e) nodule fresh mass and (f) nodule dry mass of chickpeas (Cicer arietinum L.)
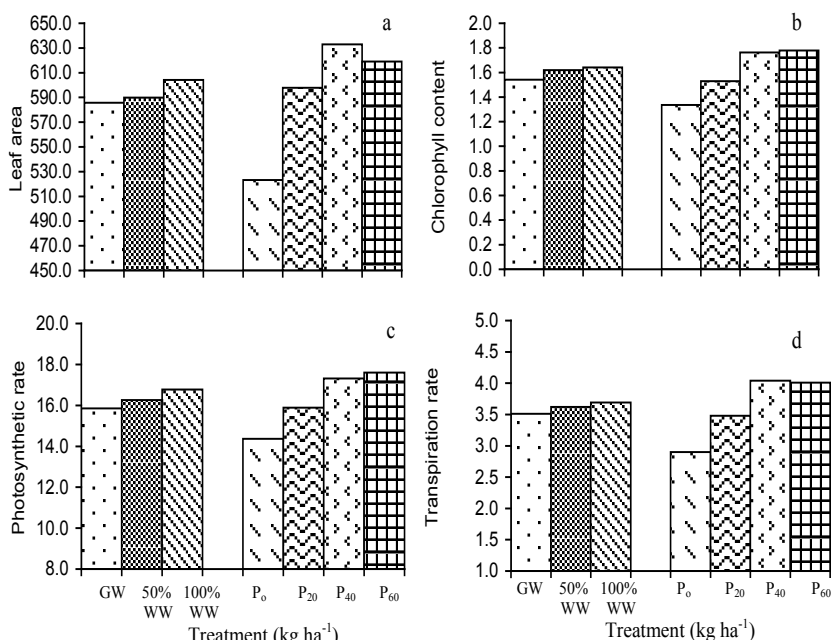

Figure 2. Figure showing the effect of different waters and phosphorus on (a) leaf area $\left[\mathrm{cm}^{2}\right]$ (b) chlorophyll content $\left[\mathrm{mg} \mathrm{kg}^{-1}\right.$ fresh mass] (c) photosynthetic rate $\left[\mathrm{n} \mathrm{mol} \mathrm{CO} \mathrm{Cm}_{2} \mathrm{sec}^{-1}\right.$ (d) transpiration rate [Trmp] of chicpea (Cicer arietinum L.)

Besides nitrogen, phosphorus when supplied in limiting amounts has much greater impact on growth than on photosynthesis and has been reported in sugarbeet[27]. During the present study better growth of plants was observed receiving wastewater having $1.42 \mathrm{mg} \mathrm{P} / 1$ (Table 1) in addition to other nutrients. The observation of the improved performance of the crop receiving it as a source of irrigation water was therefore, understandable. Although it further needs emphasis that application of phosphorus has its limitations as "P" when applied to the soil is very rapidly changed to less soluble form and therefore, becomes less and less available with time. Admittedly in short season crops, like some vegetables, growth responses to applied $\mathrm{P}$ may persist up to harvest. On the contrary, comparatively long season crops, like corn and chickpea, may show only slow growth responses and much lesser effect at seed formation and maturity. Therefore irrigation through wastewater up to close to harvest could have ensured its availability and thus might have improved the growth and development which ultimately led to higher seed productivity (Fig. 4 ).
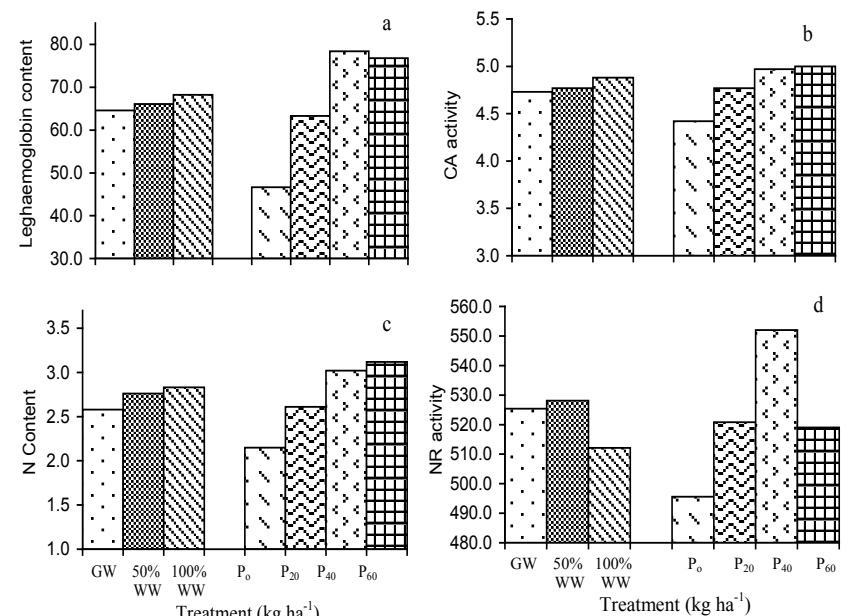

Figure 3. Figure showing the effect of different waters and phosphorus on (a) leghaemoglobin content $\left[\mathrm{mmol}(\mathrm{gm} \mathrm{FM})^{-1}\right]$ (b) CA activity [mol $\mathrm{CO}_{2} \mathrm{~kg}^{-1}$ (leaf f.m.) $\left.\mathrm{s}^{-1}\right]$ (c) $\mathrm{N}$ content [\%] (d) NR activity [noml $\mathrm{NO}_{2} \mathrm{~h}^{-1}$ $\mathrm{g}^{-1} \mathrm{FM}$ ] of chicpea (Cicer arietinum L.)
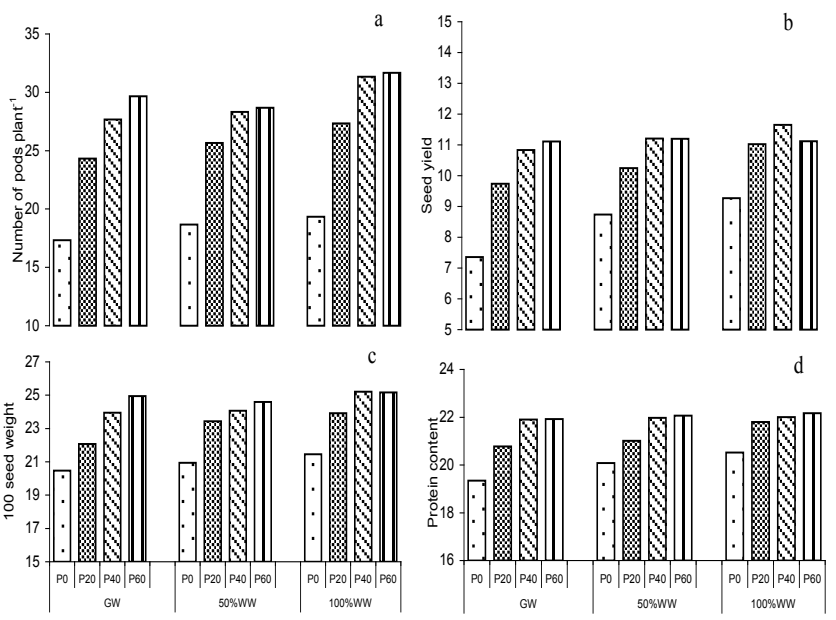

Figure 4. Figure showing the effect of different waters and phosphorus levels on yield attributes of chickpea (a) number of pods per plant (b) Seed yield $\left[\mathrm{g} \mathrm{plant}^{-1}\right.$ ] (c) 100 seed weight [g] (d) protein content [\%] (Cicer arietinum $\mathrm{L}$.) 
Similarily "K" is known to play a significant role in stomatal opening and closing[28] and under light conditions the guard cells produce abundant ATP in photosynthetic phosphorylation, thus supporting the active $\mathrm{K}^{+}$uptake with sufficient energy[29] and the resulting high turgor pressure thus causes the opening of the stomata. The diffusion of $\mathrm{CO}_{2}$ into the stomata is followed by its transport into the chloroplasts where it is reduced by ribulose-1,5-biphosphate carboxylase/oxygenase (RuBPCO). It is this supply of $\mathrm{CO}_{2}$ which catalyses reversible dehydration of $\mathrm{HCO}_{3}^{-}$to $\mathrm{CO}_{2}$ in close proximity to the $\mathrm{CO}_{2}$ fixing enzyme. The functioning of this entire mechanism is likely to be improved by enhancement of the activity of both CA which was also observed in this study (Fig. 3). It is also well known that $\mathrm{N}$ is fully utilized for crop production only when $\mathrm{K}$ is adequate[30] and the presence of $\mathrm{K}$ in wastewater was nearly double the amount present in the ground water (Table 1) and therefore, the crop under study was benefited not only due its own physiological role but also by enhancing the effect of $\mathrm{N}$. This was also strengthened by the presence of higher $\mathrm{N}$ in the leaves of the plants receiving the wastewater (Fig. 3).

The presence of other essential nutrient like sulphur could have also played a vital role in plant metabolism as its deficiency is common[31]. It may be pointed out that the application of nitrogen in the form of urea is ineffective unless sulphur is applied simultaneously and its deficiency reduces the leaf area[32] besides decreasing the chlorophyll contents[33]. In legumes during early development of sulphur deficiency, nitrogenase activity in root nodules is much more depressed than photosynthesis[34]. Moreover in sulphur deficient plants, not only the protein content decreases but also the sulphur content in the proteins indicating that the proteins with lower proportions of methionine and cysteine but higher proportion of other amino acids such as arginine and aspartate are synthesized. This decrease in the sulphur rich proteins is not confined to wheat grains but can also be found in other cereals and legumes[35] and the lower sulphur content of the proteins influences the nutritional quality considerably[36]. Although in the present study, quality of the protein was not worked out but the total protein was significantly enhanced in the wastewater irrigated plants (Fig. 4). Similarly, the presence of $\mathrm{Ca}^{2+}$ and $\mathrm{Mg}^{2+}$ (Table 1) could have further added the benefits as $\mathrm{Ca}^{2+}$ being an essential component of cell wall is involved in the cell division[37] while $\mathrm{Mg}^{2+}$ is a central atom of chlorophyll and is required for structural integrity of chloroplast[38] on which the rate of photosynthesis is directly dependent and thus rate of photosynthesis is lower in $\mathrm{Mg}^{2+}$ deficient plants[39]. It may be pointed out that the chlorophyll contents and the photosynthetic rate was enhanced in plants grown under wastewater (Fig. 2) indicating the possible involvement of $\mathrm{Mg}^{2+}$ in addition to other nutrients.

Similarly, the presence of $\mathrm{Cl}^{-}$, one of the essential micronutrients, could also have played an important role in stomatal regulation and its impairment in palm trees was considered to be the major factor responsible for growth depression[40] and reduction in the leaf surface area and there by the plant dry weight. The observed enhanced growth and photosynthetic capacity ultimately led to increase in 100 seed weight (Fig. 4) because of the ensured supply and availability of above mentioned nutrients might have played a cumulative role in enhancing the metabolic activities and finally the seed yield and protein content (Fig. 4). Besides the nutrient content of the wastewater, the presence of some heavy metals can be a cause of concern indicating the possibility of their accumulation in plants (Table 1 and 3). Although these concentrations remained well within the limits permissible[41] but regular monitoring must be mantained for safe use of wastewater in crop cultivation as the continuous application may lead to their buildup $[42,18]$. In addition to this, the microbial examination of wastewater revealed the presence of some pathogenic and non pathogenic bacteria (Table 2) which can be a cause of concern however, in our case since the crop is not eaten raw therefore, the chances of harm are comparatively negligible to consumers although the growers must be warned to take precautions while applying the wastewater to their crops in the fields.

Four different phosphorus applied included $\mathrm{P}_{0}, \mathrm{P}_{20}, \mathrm{P}_{40}$, $\mathrm{P}_{60}$, as it is indispensable for plant growth and development and its deficiency retards plant growth, cell and leaf expansion[43]. It has many roles in cell division, stimulation of early root growth, hastening plant maturity and fruiting and seed production. Application of $\mathrm{P}$ thus promoted growth and the effect was significant at both 60 and 90 DAS, being more pronounced when given with wastewater. Phosphorus at $40 \mathrm{~kg} \mathrm{ha}^{-1}$ proved optimum for shoot and root length and plant fresh and dry mass (Fig. 1).

The leaf area was also increased under this treatment (Fig. 2) and it was at par with $60 \mathrm{~kg} \mathrm{ha}^{-1}$ thereby showing the luxury consumption of phosphates. The beneficial effect of phosphorus on the leaf area has also been reported by Rao and Subramanian[44] in cowpea and Reddy et al.[45] in ground nut. The importance of leaf area in terms of leaf area index as determinant of radiation interception has been recognized in field crops[46] and is also known to improve the rate of assimilate production per unit leaf area as reported by Jacob and Lawlor[47] and as also observed in the present study (Fig. 2 ). On the contrary, the most striking effects of phosphorus deficiency are reduction in leaf expansion and leaf surface area[48] and also the number of leaves as may be observed under $\mathrm{P}_{20}$ which proved as deficient dose (Fig. 2) and which is common when the concentration of an essential element is low and often results in limiting the yield and although under moderate or slight deficiencies symptoms may not be visible, but yields may still be reduced. While under optimum level, plant dry matter was increased (Fig 1) and in combination with wastewater accumulated more dry mass indicating the possible role of $\mathrm{P}$ given as fertilizer and nutrients present in the wastewater which was evident from higher $\mathrm{N}$ content in the leaves (Fig. 3). Increases in the dry matter accumulation 
due to $\mathrm{P}$ fertilizer has also been reported in chickpea by Khokar and Warsi[49] who have observed that legumes show an evident preference of phosphatic fertilizers. It may be pointed out that the differences in the dry matter among different $\mathrm{P}$ fertilizer doses were probably caused due to the differences in the leaf area (Fig. 2) which enabled the plants to produce more photosynthates because of higher photosynthetic activity (Fig.2 ) leading to more pods and higher seed weight (Fig. 4). In addition, the chlorophyll contents (Fig. 2) were also improved and there are reports wherein insufficient $\mathrm{P}$ has been shown to limit chlorophyll and protein content[50].

Furthermore $\mathrm{P}$ in leaf tissues is known to be responsible for phosphorylation and release of photosynthates from chloroplast and oxidation of these sugars to produce

more reducing power for nitrate metabolism. In case of photosynthestic activity, deficiency of $\mathrm{P}$ was found to decrease it in spinach[51], tobacco[52] and subterranean clover[53] which was also reflected under $\left(\mathrm{P}_{20}\right)$ the deficient dose of phosphorus (Fig 2). This inhibition of photosynthesis by $\mathrm{P}$ limitation has often been explained by depressing Calvin cycle activity in particular and also by decreasing the amount and activity of rubisco[54]. Similarly, the decline in the stomatal conductance (Fig. 2) leading to decrease in the photosynthetic rate (Fig. 2 ) has also been reported by Xu et al. [50].

Legumes also require phosphorus for nitrogen fixation and if its availability is limited, growth and nitrogen fixation are adversely affected[55]. Thus in present study the fresh and dry mass of nodules (Fig.1) were increased with increasing $\mathrm{P}$ levels up to $\mathrm{P}_{40}$ however, $\mathrm{P}_{60}$ could not increase it further while the wastewater with $\mathrm{P}_{40}$ improved it. Robson et al.[56] had also reported $\mathrm{P}$ nutrition increased symbiotic dinitrogen fixation in subterranean clover (Trifolium subterranean L.) by stimulating host plant growth rather than by exerting specific effects on Rhizobial growth or on nodule formation and function. Under this study similar observations were made where shoot growth and root growth (Fig 1) were enhanced significantly under $\mathrm{P}_{40}$. There are instances where, it has been observed that the dinitrogen fixation by Rhizobium is enhanced if the plants are better supplied with $\mathrm{P}$ along with $\mathrm{K}$ [57] and in the present study besides the phosphorus levels the wastewater ensured its uninterrupted supply.

The increase in plant $\mathrm{N}$ concentration in response to increased $\mathrm{P}$ supply has also been noted for several leguminous species[58]. Consequently, application of $\mathrm{P}$ also proved valuable for seed protein content (Fig.4) due to its assured availability and utilization by carbon skeletons for amino acid synthesis as well as for energy rich ATP. Being a part of the protein molecules enhanced $\mathrm{N}$ levels due to the application of $\mathrm{P}$ might have triggered and maintained the conversion of various organic acids (produced from carbohydrates during respiration) into amino acids. Beneficial effects of phosphorus application on seed yield and quality compared to control have also been reported in cluster bean by Bhadoria et al.[59], on LAI, biological index and seed yield on Pisum sativum by Yamane and Skjelvag[60] and in legumes by a number of authors including Berg and Lynd[61]; French[62] and Bolland et al.[63].

\section{Conclusions}

Based on these findings we can conclude that the urban wastewater proved beneficial for the crop growth and productivity. The wastewater proved an effective source of essential nutrients and reduced the quantity of phosphorus doses and thus acted not only as a source of irrigation water but of nutrients also. Although the presence of some microbes could be a cause of concern but since in our case the crop is eaten only after cooking so it does not seem to pose any harm. Also the presence of heavy metals were detected in wastewater but it does not seem to have affected the crop much but its continuous usage may result in their buildup to phytotoxic level and thus regular monitoring is required for the safe irrigation and benefits, so that its reuse can effectively contribute to fill the increasing gap between water demand and water availability.

\section{ACKNOWLEDGEMENTS}

Hamid Iqbal Tak thanks the NWU for awarding the Post-doctoral research fellowship.

\section{REFERENCES}

[1] Postel, S. (1999). Pillars of sand: Can the irrigation Miracle Last? New York: W.W Norton. In: Agricultural sustainability, Principles, Processes, and Prospects. pp. 166. Raman, S. Food Product Press, New York

[2] Rosegrant, M.W. (1995). Dealing with water scarcity in the next century. Vision 2020 Brief 21. Washinton, DC: International Food Policy Research Institute. In: Agricultural sustainability, Principles, Processes, and Prospects, Raman, S. Food Product Press, New York. pp. 154

[3] FAO. (1996). Food production: Critical role of water. Technical background paper, World Food Summit, Rome: Food and Agricultural Organisation

[4] Reddy, M.S. (1993). National water policy. Operation issues- Keynote address. In: Proceedings of National workshop on action plan for optimum utilization of water resources. Water and power consultancy services (India) Limited, New Delhi. pp. 1-274

[5] Bhardwaj, R.M. (2005). Status of wastewater generation and treatment in India. IWG- Env joint work session on water statistics, Vienna, 20-22 june

[6] Feigin, A., Vaisman, I. and Bielorai, H. (1984). Drip irrigation of cotton with treated municipal effluents: II. Nutrient availability in soil. J. Environ. Qual., 13: 234-238

[7] Wang C, Zhang SH, Wang PF, Hou J, Li W, Zhang WJ 
(2008). Metabolic adaptations to ammonia-induced oxidative stress in leaves of the submerged macrophyte Vallisneria natans (Lour.) Hara, Aquat. Toxicol., 87(2): 88-98 2008

[8] Standard Methods for examination of water and wastewater., 1985. $16^{\text {th }}$ Ed., APHA- AWWA- WPCF, New York

[9] Jackson, M. L. 1973. Soil chemical analysis, Prentice Hall of India, New Delhi

[10] Ghosh, A. B., Bajaj, j. C., Hassan, R., Singh, D. 1988: Soil and Water Testing Methods, A Lab. Manual, IARI, New Delhi

[11] Jaworski, E.G. (1971). Nitrate reductase assay in intact plant tissue. Biophys. Res. Comm., 43: 1274-1279

[12] Lindner, R.C. 1944. Rapid analytical methods for some of the more inorganic constituents of plant tissues. Plant Physiol., 19: 76-89

[13] Mackinney, G., 1941. Absorption of light by cholorophyll solutions. J. Biol. Chem. 140, 315-322

[14] Lowry, O.H., Rosebrough, N.J., Farr, A.L. and Randall, R.J. 1951. Protein measurement with Folin phenol reagent. J. Biol. Chem., 193: 265-275

[15] Gomez, K. A., Gomez, A. A. 1984. Statistical procedure for agricultural research. Wiley, New York

[16] Ayers, R. S., Wescot, D. W., 1994. Water quality for agriculture: FAO irrigation and drainage paper. 29. Rev., 1. $1-130$

[17] Vazquez-Montiel, O., Horan, N.J. and Mara, D.D. (1996). Management of domestic wastewater for reuse in irrigation. Water Sci. Tech., 33: 355-362

[18] Tak, H. I, Inam. A and Inam, A. (2010). Effects of urban wastewater on the growth, photosynthesis and yield of chickpea under different levels of nitrogen. Urban Water Journal, 7(3), $187-195$

[19] Kirkby, E.A. (1981). Plant growth in relation to nitrogen supply. In:Terrestrial nitrogen cycles. Processes, Ecosystem strategies and Management impacts. pp. 249-267. F.E. Clarke and T. Rosswall (eds.), Ecol. Bull., Stockholm 33

[20] Maynard, D.N. and Barker, A.U. (1969). Studies on the tolerance of plants to ammonium nutrition. J. Am. Soc. Hortic. Sci., 94: 235-239

[21] Weissman, G.S. (1964). Effects of ammonium and nitrate nutrition on protein level and exudate composition. Plant Physiol., 39: 947-952

[22] Cox, W.J. and Reisenauer, H.M. (1973). Growth and ion uptake by wheat supplied nitrogen as nitrate or ammonium or both. Plant Soil., 38: 363-380

[23] Taylor, G., McDonald, A.J.S., Stadenberg, I. and Freer-Smith, P.H. (1993). Nitrate supply and the biophysics of leaf growth in Salix viminalis. J. Exp. Bot., 44: 155-164

[24] Gastal, F. and Lemaire, G. (2002). N uptake and distribution in crops: an agronomical and ecophysiological perspective. $J$. Exp. Bot., 53: 789-799

[25] Lemaire, G. (2001). Ecophysiology of grassland: dynamic aspects of forage plant population in grazed swards. In: Proceedings of the XIX International Grassland Congress,
Brazil. pp. 29-37

[26] Terashima, I. and Evans, J.R. (1988). Effects of light and nitrogen nutrition on the organisation of the photosynthetic apparatus in spinach. Plant Cell Physiol., 29: 143-155

[27] Rao, I.M. and Terry, N. (1989). Leaf phosphate status, photosynthesis in vivo in sugar beet. I. Changes in growth, photosynthesis and Calvin cycle enzymes. Plant Physiol., 90: 814-819

[28] Fischer, R.A. and Hsiao, T.C. (1968). Stomatal opening in isolated epidermal strips of Vicia faba. II. Responses to $\mathrm{KCl}$ concentration and the role of potassium adsorption. J. Plant Physiol., 43: 1953-1958

[29] Humble, G.D. and Hsiao, T.C. (1970). Light dependent influx and efflux of potassium of guard cells during stomatal opening and closing. Plant Physiol., 46: 483-487

[30] Mengel, K. and Kirkby, E.A. (1982). Principles of plant nutrition. In: Potassium in Agriculture, 1985. pp. 515. R.D. Munson (ed.), Publ. by ASA-CSSA-SSSA, Madison, WI, U.S.A

[31] Murphy, M.D. and Boggan, J.M. (1988). Sulphur deficiency in herbage in Ireland. I. Causes and extent. Irish J. Agric. Res., 27: 83-90

[32] Wang, C.H., Liem, T.H. and Mikkelsen, D.S. (1976). Sulphur deficiency- a limiting factor in rice production in the lower Amazon basin. II. Sulphur requirement for rice production. IRI Res. Inst., 48: 9-30

[33] Deitz, K.J. (1989). Recovery of spinach leaves from sulphur and phosphate deficiency. Plant Physiol., 134: 551-557

[34] DeBoer, D.L. and Duke, S.H. (1982). Effect of sulphur nutrition on nitrogen and carbon metabolism in lucerne (Medicago sativa L.). Physiol. Plant., 54: 343-350

[35] Randall, P.J. and Wrigley, C.W. (1986). Effect of sulphur supply on the yield, composition, and quality of grain from cereals, oil seeds and legumes. Adv. Cereal Sci. Technol., 8: 171-206

[36] Arora, S.K. and Luchra, Y.P. (1970). Metabolism of sulphur containing amino acids in Phaseolus aureus Linn. Z. Pflanzenernahr. Bodenk., 126: 151-158

[37] Schmit, J.N. (1981). Le calcium dans le cellul generation en mitrose. Etude dans le tue pollinque en germination du clivia nobilis Lindl (Amaryllidaceae) C. R. Acad. Sci. Ser. (III) higher plants. Academic Press, London

[38] Moorby, J. and Besford. R.T. (1983). Mineral nutrition and growth. In: Encyclopedia of Plant Physiology. 15B: 481-527. A. Lauchli and R. L. Bieleski (eds.), Springer Verlag, New York

[39] Forster, H. (1980). Einfluss von unterschiedlich starkem Magnesiummangel bei Gerste auf den kornertrag und seine Komponenten. Z. Pflanzenernahr. Bodenk, 143: 627-637

[40] Braconnier, S. and d'Auzac, J. (1990). Chloride and stomatal conductance in coconut. Plant Physiol. Biochem., 28: $105-112$

[41] Pendias, A. K. and Pendias, H. (1992). Trace elements in soils and plants. CRC Press, Inc. Boca Raton, Florida

[42] Aziz, O., Inam, A. and Samiullah. (1999). Utilization of 
petrochemical industry wastewater for agriculture. Water Air Soil Pollut. 115: 321-335

[43] Marschner, H., 1995. Mineral nutrition of higher plants, second ed. Academic Press, New york

[44] Rao, D.G. and Subramanian, V.B. (1990). Effect of P on nodulation, $\mathrm{N}$ harvest index and growth correlations between nodulation and other plant parts in cowpea under well-watered and dryland conditions. Indian J. Plant Physiol., 33: 275-281

[45] Reddy, K.B., Reddy, D.S. and Reddy, C.M. (1991). Evaluation of groundnut genotypes for phosphorus use efficiency. Indian J. Plant Physiol., 34: 228-234

[46] Kumar, S., Singh, J. and Dhingra, K. K. (1997). Leaf area index relationship with solar radiation interception and yild of Indian mustard (Brassica juncea) as influenced by plant population and nitrogen. Indian J. Agron., 42: 348-351

[47] Jacob, J. and Lawlor, D.W. (1991). Stomatal and mesophyll limitations of photosynthesis in phosphate deficient sunflower, maize and wheat plants. J. Exp. Bot., 42: 1003-1011

[48] Fredeen, A.L., Rao, I.M. and Terry, N. (1989). Influence of phosphorus nutrition on growth and carbon partitioning in Glycine max (L.) Plant Physiol., 89: 225-230

[49] Khokar, R.K. and Warsi, A.S. (1987). Fertilizer response studies in gram. Indian J. Agron., 32: 362-364

[50] Xu, H.X., Weng, X.Y. and Yang, Y. (2007). Effect of phosphorus deficiency on the photosynthetic characteristics of rice plants. Russ. J. Plant Physiol., 54: 741-748

[51] Bottrill, D.E., Possingham, J.V. and Kriedemann, P.E. (1970). The effect of nutrient deficiencies on photosynthesis and respiration in spinach. Plant Soil., 32: 424-438

[52] Kakie, T. (1970). Effect of phosphorus deficiency on photosynthetic carbondioxide fixation-products in tobacco plants. Soil Sci. Plant Nutr., 15: 245-251

[53] Bouma, D. (1967). Growth changes of subterranean clover during recovery from phosphorus and sulphur stresses. Aus.
J. Biol. Sci., 20: 51-66

[54] Stark, Z., Niemyska, B., Bogdan, J. and Akour Tawalbeh, R.N. (2000). Response of tomato plants to chilling stress in association with nutrient or phosphorus starvation. Plant Soil., 226: 99-106

[55] Prasad, J. and Sanoria, C.L. (1981). Response of Bengal Gram to seed bacterium and phosphorus. Seeds and Farms. 7: 31-32

[56] Robson, A.D., O’Hara, G.W. and Abbott. L.K., (1981). Involvement of phosphorus in nitrogen fixation by subterranean clover (Trifolium subterraneum L.) Aust. J. Plant Physiol., 8: 427-436

[57] Mengel, K., Haghparast, M.R. and Koch. (1974). The effect of potassium on fixation of molecular nitrogen by roots of Vicia faba. Plant Physiol., 54: 535-538

[58] Israel, D.W. (1993). Symbiotic dinitrogen fixation and host plant growth during development of and recovery from phosphorus deficiency. Physiol. Plant., 88: 294-300

[59] Bhadorai, R.B.S., Tomar, R.A.S., Khan, H., Sharma, M.K. (1997). Effect of phosphorus and sulphur on yield and quality of cluster bean (Cymopsis tetragonoloba). Indian $J$. Agron., 42: 131-134

[60] Yemane, A. and Skjelvag, A.O. (2003). Effect of fertilizer phosphorus on yield traits of Dekoko (Pisum sativum var. Abyssinicum) under field conditions. J. Agron. Crop Sci., 189: $14-20$

[61] Berg, R.K. and Lynd, J.Q. (1985). Soil fertility effects on growth, yield, nodulation and nitrogenase activity of Austrian winter pea. J. Plant Nutr., 8: 131-145

[62] French, R.J. (1990). The contribution of pod numbers to field pea (Pisum sativum L.) yields in a short growing season environment. Aust. J. Agric. Res., 41: 853-862

[63] Bolland, D.A., Riethmuller, G.P., Siddique, H.M. and Loss, S.P. (2001). Methods of phosphorus application and row spacing on grain yield of faba bean (Vicia faba L.). Aust. J. Exp. Agric., 41: 227-234 